International Journal of Public Policy and Administration

Research

2018 Vol. 5, No. 1, pp. 24-36

$\operatorname{ISSN}(e): 2312-6515$

$\operatorname{ISSN}(p): 2313-0423$

DOI: 10.18488/journal.74.2018.51.24.36

(C) 2018 Conscientia Beam. All Rights Reserved.

(T) Cheok for updates

\title{
PARTICIPATORY PROCESSES IN PLANNING FOR SELF-HELP HOUSING PROVISION IN SOUTH AFRICA: POLICIES AND CHALLENGES
}

\author{
Sithembiso \\ Lindelihle Myeni ${ }^{1}$ \\ Bongekile YC \\ Mvuyana $^{2+}$
}

\author{
${ }^{\prime}$ University of KwaZulu-Natal, School of Built Environment \& \\ Development Studies, South Africa \\ ${ }^{\circ M a n g o s u t h u}$ University of Technology, Department of Public \\ Administration, South Africa \\ Email:mvuyana@mut.ac.za
}

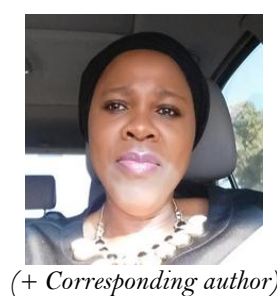

ABSTRACT
Article History

Received: 9 January 2018 Revised: 26 April 2018 Accepted: 30 April 2018 Published: 2 May 2018

\section{Keywords}

Governmentality Participatory processes

Self-help

Rural housing

Power

Traditional council.

\begin{abstract}
In contemporary post-apartheid a number of housing policies have been made since the 1994 democratic dispensation in an attempt to solve housing problems especially for poor and low-income population in South Africa. The most recent policy has been the Comprehensive Housing Plan for the Development of Integrated Sustainable Human Settlements commonly known as the Breaking New Ground (BNG) housing plan of 2004. The aims of this paper are to present an overview and empirical analysis on research and emerging legitimisation of the participation of informal institutions in planning phase for housing development in rural areas. This paper analyses public participatory processes in the planning phase of rural housing project(s) in Jozini Municipality in KwaZulu-Natal. Since the establishment of a fully-fledged local government institutions and the promulgation of the BNG in 2004, inhabitants have experienced materialisation of new housing opportunities for community members. These opportunities created during the planning phase which results to community members benefiting in housing development excludes the poor in the process of selfhelp subsidy administration and housing allocation. Grounded on the works of Foucauldian scholars especially the 'discourse of power' in participation, the paper argues that the local community members not only embody the local knowledge to be accessed, but their participation presents an important entry point to the political decision-making needed for collecting differing viewpoints and interests but also for initiating the negotiations needed that would lead to coordination, if not cooperation for housing development. We propose that participatory processes that are beneficiary to the poor are best understood when traced over time as a dynamic response to a constantly unfolding-project related intervention.
\end{abstract}

Contribution/Originality: This study contributes in the existing literature on self-help housing and applies Foucauldian approach in order to present how the participation of informal institutions in the planning phase for housing development in rural areas was legitimated.

\section{INTRODUCTION}

From the late 1980s, mainstream discourse and participatory agenda have encompassed processes of governance where participatory processes have become key to access to housing and linked to technologies of power that aim to legitimate the political agendas of global institutions. Some authors like Cleaver (1999) drawing from participatory literature in development argues that literature in development maintains oversimplified ideas about the beneficial nature to individuals of participation overlooking the potential links between inclusion and 
possible subordination. Ferguson (2010); Dean (1999) and others argue that development has been a machinery of power for producing knowledge about and exercising control over so-called "developing" countries. From these studies we learn how development operates as a ruling apparatus and gives rise to technologies, experts and apparatuses for the administration and transformation of many peoples' lives and for courses of action aimed at the global South for over half a century (Dean, 1999; Ferguson, 2010). However, the purpose of participatory processes in planning is to enable those individuals and groups previously excluded by more top-down planning processes, and who are marginalized by their separation and isolation from the production of knowledge and their formulation of policies and practices to be included in decisions that affect their lives.

There have been numerous reviews and critiques of participatory processes and government housing policy in South Africa (Cleaver, 1999; Seekings, 2000; Kothari, 2001). These take two main forms: those that focus on the administrative limitations of participatory processes, which stress the need for re-examination of the methodological tools used in planning phase, and those that pay closer attention to the theoretical and conceptual as well as policy limitations. Proponents of administrative practices argue that government housing policy has focused on ensuring the delivery of houses to the people rather that the participatory provision of housing. Critics of 1994 Housing White Paper (HWP) argue that it took a progressive approach to housing, which is developer driven approach that limits participation of ordinary citizens in the provision of housing, despite the government's commitment to enabling participation. We want to move between these critiques by examining the techniques of knowledge accumulation about identifying housing beneficiaries and process of information exchange that take place during planning phase of self-help housing provision in order to identify and highlights the forms of control and power articulated by participatory processes through the particular social interactions that take place.

Our argument is informed by governmentality literature. Since participatory processes in housing development is a technique for knowing housing beneficiaries, underlying the discussion in this paper is an analysis of the techniques of power and particular types of knowledge that the process creates and reproduces. Focusing upon apparatuses of governance that operate within and at a distance from the formal institutions of the state, this governmentality literature views government as consisting of calculated and rationalized activities undertaken by authorities and agencies employing various strategies, technologies, programmes and languages to shape capacities and conduct (Dean, 1999). The "art" of government, in this sense, involves the practices of non-state actors, including citizens, traditional councils, implementing agents and state actors in government relationships (Dean, 1999) and opens up new ways of configuring problems and assembling solutions to resolve them.

This paper aims to present an overview and empirical analysis on research and emerging legitimization of the participation of informal institutions - traditional councils in planning phase for housing development in rural areas. This paper analyses the value public participatory processes of beneficiaries in the planning phase of rural housing project(s) in Jozini Municipality in KwaZulu-Natal. However, effective participatory processes necessitate particular forms of representation for beneficiaries. Designing an effective participatory mechanism thus requires paying attention to new practices of representation as well as new practices of participation. In the participatory housing processes in particular such representation is essential as the direct participation of communities in decision making might not be feasible at some points in the process, hence, community residents need people that will communicate and make decisions on their behalf in engaging with government. This is the gap that this study explores in relation to housing through a case-study of the role of local community leaders and traditional councils in rural housing project(s) in Jozini Municipality. It aims to understand the significance of the representative role played by local leaders and traditional councils who are not part of the formal democratic system of representation in development participatory processes.

Grounded on the works of Foucauldian scholars especially the 'discourse of power' in participation, the paper argues that the local community members not only embody the local knowledge to be accessed, but their participation presents an important entry point to the political decision-making needed for collecting differing 
viewpoints and interests but also for initiating the negotiations needed that would lead to coordination, if not cooperation for housing development. According to Foucault (1980) power must be analyzed as something which circulates, or rather as something which only functions in the form of a chain. It is never localized here or there, power is employed and exercised through net-like organization. Accordingly, Foucault's analysis of power requires us to shift our concentration from the centre and national institutions such as state not because this enables the powerless to speak and be heard, but because those macro-spheres of authority are not necessarily the only focal conductors of power (Kothari, 2001). Foucault (1980) maintains the need to explore further the local and micropoints of power because 'hegemonic or global forms of power rely in the first instance on those 'infinitesimal' practices, composed of their own particular techniques and tactics, which exist in those institutions on the fringes or at the micro-level of society'.

According to Kothari (2001) power is everywhere and can be analyzed through the creation of social norms or customs that are practiced throughout society. This understanding disrupts the dichotomies of central/local, macro/micro, powerful/powerless, where the former are sites and holders of power and the latter are subjects of power. This shows that everyone or all individuals are vehicles of power. An analysis of the ways in which power extends and transforms in different micro - or 'everyday' contexts can further our understanding of the more readily identifiable types of social control and domination traditionally seen to be located at the 'centre', be they at the level of the state or other global institutions or in the hands of local elites. Accordingly power is thus found in the creation of norms and social and cultural practices at all levels. Kothari (2001) further argues that knowledge is culturally, socially and politically produced and is continuously reformulated as a powerful normative construct. As a result, knowledge is thus an accumulation of social norms, rituals and practices that, far from being constructed in isolation from power relations, is embedded in them.

This paper is manifold. It starts with literature which provides historical overview of self-help housing relevant to understanding participatory processes in planning and thus covering different types of self-help housing. The second section covers research design and methodology. The third section applies Foucauldian concept of power in participatory processes in planning phase for self-help housing provision in South Africa. The fifth and final section concludes the paper.

\section{LITERATURE REVIEW}

Since the 1960s much literature on self-help housing has been documented as an approach in housing literature. According to Pugh (2001) self-help housing practice has existed among cultures of developing countries since time immemorial before conventional town planning and housing knowledge. In the 1930s and early 40s, self-help housing schemes became common in developing countries prior to the Second World War through the implementation of pilot housing schemes by the International Cooperation Administration (formally Housing and Home Finance Administration), a United States Agency, in Latin American countries (Mathey, 1997; Tait, 1997; Harris, 1998). However, the British architect Turner in the mid-1960s was opportune to implement the concept of self-help housing expanding the concept through theoretical writings and thus further shaping and influencing the interest and practice of self-help housing (Turner, 1972; Ward, 1982; Harris, 1998; Ntema, 2011). In essence, internationally, the formal adoption of self-help is to a greater extent believed to be the influence of Turner and Mangin's experience and writings on Peru in the 1960s. Even though their work was centered in Latin America, their intellectual influence extended across the world and well into the policy priorities of the World Bank in the 1970s. Proponents of the self-help approach considered housing security as the prime requirement for such selfbuild processes to succeed (Harris, 1998).

Turner's main view on self-help housing concept is anchored on the freedom-to-build of which dweller control is paramount to the success of any housing programme (Harris and Giles, 2003; Ntema, 2011) in order to overcome bureaucratic and technological barriers (Ward, 1982). Hence, decisions regarding housing provision for the 
populace should be controlled by the dwellers in a bottom-up approach, since this will affect the construction process and quality of the houses corresponding to dweller economic, social and cultural characteristics (Ntema, 2011). According to Stein (1991) and Soliman (2004) this proposition by Turner reflected more non-Marxist viewpoints that lacked capitalist (or Marxist) ideas of seeing housing as commodity with use value and market value. The Marxist ideas pursued by Burgess (1977) argued that self-help housing becomes cheaper with the removal of paid labour (sweat equity) of the dweller not the absence of profits which relieves the government of some expenses on the poor (Stein, 1991). In addition, it must be mentioned that the self-help approach was criticized by other scholars, e.g. Burgess (1977); Ward (1982) and Mathey (1997).

Self-help housing has been given various definitions by various authors (Dewar et al., 1981; Zhang et al., 2003). For instance, self-help housing has been defined as 'practices in which low-income groups solve their housing needs primarily through their own resources of labour and finance'. In essence, it means that inhabitants are rendered responsible for overcoming the often structural problems thrown up by uneven development via 'government by community' practices (Rose, 2000). Ntema (2011) also defined self-help housing as one that allows poor communities to act as key decision makers in project planning, design, management and implementation with state support in initial project funding, training on project management and oversight during implementation.

Literature shows that over the decades self-help housing has developed a number of variants that include; 1) aided self-help housing, 2) unaided [laissez-faire] self-help housing, and 3) institutional self-help housing. Sengupta (2010) confirms these developed variants, as he noted that 'different observable types of self-help were private selfhelp in both individual and collective levels, state-initiated self-help and state-assisted self-help. Pugh (2001) describes aided self-help housing as a housing scheme in which site-and-services are provided with the individual household taking responsibility for the construction of their own housing units. Unaided self-help housing however, refers to a housing concept where the government plays no role, thus individuals or households acquire all materials and labour and finances to complete their housing unit on a plot of land purchased by households. Laissezfaire self-help housing is very common among middle to high income groups particularly in informal settlements with limited state control (Duncan and Rowe, 1993; Harris, 1998). Institutional self-help housing according to Ntema (2011) refers to implementation of self-help housing through community-based institutions or groups known as housing cooperatives'. One can conclude that self-help is not practiced by the low income households but also by both middle and high income households.

This paper argues that Sengupta's different types of self-help remain crucial in this paper. The focus of this paper will be on the participatory processes of the planning phase of state-initiated self-help in Jozini Municipality. We are aware that the delivery of housing in post-apartheid South Africa is characterized by three streams of delivery, namely private sector housing, state housing and self-help housing. For example, Enhanced People's Housing Process (ePHP) is an official self-help housing mechanism which allows groups of people to work together to pool their resources and contribute their labour to build homes. It is evident that after 1994 formal state-initiated self-help (see Myeni and Mvuyana (2015)) process constitutes a large percentage of the current housing stock in terms of housing provision for lower income households and offer an efficient mechanism to bypass many complexities that come with conventional mortgage loan system and provide a reasonable house without any input required from the beneficiaries, while legitimating the political agenda of the ANC-led government or administration and the housing policy reforms they promote. The state-initiated self-help housing process in South Africa is mainly characterized by bureaucratic practices where government initiates the project, procures and registers the land, procures designs and building materials, and procures development and building permit. Therefore, the dominant of state-initiated self-help housing provision has resulted in a situation due to increased expectations where low-income households would rather wait for a state provided house than building their own. In addition, in a state-initiated self-help housing provision the state enables and facilitates the process with private sector contributing with their expertise; and all processes are financed by the state, while the beneficiaries are 
expected to avail land in rural areas; hence providing a viable mechanism for state-initiated self-help housing. The state-initiated self-help model is regulated and usually follow formal planning procedures during their implementation that includes the delivery of limited infrastructure and services during the construction of the houses.

\section{RESEARCH DESIGN AND METHODOLOGY}

This research takes the form of a qualitative field study carried out at a rural local government - Jozini Municipality. The case material was collected through a series of interviews on the procedures and processes on the selection of housing beneficiaries of self-help housing. We set out initially to determine the role of the municipality and traditional councils in housing provision in the post-apartheid South Africa. In particular, did new housing policies have repercussions for the management of housing development for rural development? We opted to focus on rural housing scheme as one of a specific set of tangibles that emerged as strategic to promote both partisan and territorial interests of the ANC-led government.

We interviewed members of various spheres and functions in the government and in community structures, including street-level bureaucrats in planning and technical services, who worked in different spheres of government - provincial and local, members of ward committees and project steering committee(s) as well as members from traditional councils and political parties in both ruling and opposition. We asked broad questions about their daily work, the kind of measurements and criteria they used in selecting housing beneficiaries and their work relations with people inside and outside their department(s) or team during the planning phase. All participants spontaneously mentioned working as a team with existing community structures and street-level bureaucrats from different agencies in order to identify housing beneficiaries for state-initiated self-help housing during planning phase.

22 semi-structured interviews in all were conducted between 2014 and 2015, each lasting from 45 to 120 minutes. All interviews were fully recorded and transcribed; this produced a volume of approximately 189 pages from 22 hours of interviews. Certain informants were interviewed more than once especially street-level bureaucrats; this allowed the researcher to document changes taking place in the process of housing development, and clarify issues that emerged as the field study progressed. Obtaining convergent discourses from the same person, interviewed several months apart by different researchers asking questions about different issues, also strengthened our confidence in the empirical findings. We provide extensive examination official policy documents from government and in both technical and experts' reports from housing implementing agent(s) in order to understand the implementation of housing policies. We also used data from housing subsidy system, and our data analysis is informed by Foucault's conceptualization of the discourse of power. We thus identify what is and is not valued within the analysis of housing literature, then trace the antecedents and consequences of the introduction of a new generation of actors in housing development to understand the links between the discourse of consensus, technology of rule, processes and practices.

\section{DATA ANALYSIS AND INTERPRETATION}

\subsection{The Purification of Knowledge and Space}

The third section applies Foucauldian concept of power in participatory processes in planning phase for stateinitiated self-help housing provision in South Africa. One of the aims of the participatory processes in state-initiated self-help housing provision is to uncover the voices of the marginalized and excluded, but this can be problematic when the knowledge produced challenges knowledge conventions (Kothari, 2001). Sibley (1995) argues that 'when dissenting, radical ideas are produced by members of social groups who are themselves marginalized and excluded from centres of power, the threat of establishment may be more tangible than when it comes from within'. Kothari (2001) argues that the discourse of power in participation has a tendency of promoting the purification of space by 
the exclusion or rejection of certain people and certain forms of knowledge. The practices of the purification of space in hardly captured in the field of housing research, and the next section captures this in the following analysis.

\subsection{Beneficiary Qualification and Bureaucratic Processes}

The post-apartheid policy regime has not changed the beneficiary qualification criteria for state-initiated selfhelp housing provision, but it was noted that there are additions to the rural housing scheme to reflect the combination of both direct and indirect technology of rule. The policy stipulates that qualifying households should earn less than R3 500 per month. People married in terms of civil or customary law, as well as couples living together but not married, also qualify. The beneficiaries must be lawful South African citizens or permanent residents. Recipients of the subsidy must be over 21 years of age, legally competent to contract, and have financial dependents. The eligibility criteria exclude young mothers, most of whom give birth to their first child before the age of 21 . Furthermore, the requirement to have dependents for adults over 21 excludes those who may qualify because of their low or lack of income (Ndinda et al., 2011). However, such adults are disqualified because of lack of dependents, thus relegating them to the masses of housing poor. Moreover, the requirement of citizenship disqualifies adults who lack South African identity documents. Overall, these requirements which are implemented by government officials through technocratic rationalities which serve as a technology of control, where the state has a strong control as to who benefits and who does not in housing provision, relate to the politics of means testing.

The original criteria for eligibility to state-initiated self-help housing provision have remained the same, although there have been modifications to accommodate the needs of indigent groups, such as the health stricken and orphaned and vulnerable children as well as aged and women-headed households. In addition, a beneficiary qualification criterion for a rural subsidy is the informal rights to land, which also guarantees that both ward committees and traditional councils play a role in compilation of the housing list for beneficiaries. Hence households earning below R3 500 a month are eligible for the full subsidy amount, which is adjusted on an annual basis due to inflation.

Furthermore, the Department of Human Settlements (DoHS) through bureaucratic processes and technicalities receives subsidy applications of intended beneficiaries to state-initiated self-help housing provision through the implementing agent for them to approve. This means intended beneficiaries have no direct role in the process and no power to influence the final outcome of the approval, even if rejected. Applicants do not have autonomy to engage in negotiations of their own behalf and remain dependent on officials through implementing agent(s). The bureaucratic complexity of the DoHS to hold power in order to prevent municipalities from diverting funds for their purposes does not make it attractive to intended beneficiaries, since they are restricted to direct contact with streetlevel bureaucrats, which reduces the discursive space in which housing questions would be redressed about rejection of applications.

The DoHS is backed by the Constitution (especially Schedule 4) which gives the provincial government a role to ensure that the constitutional right of adequate housing in the province is met through formulation of a provincial housing policy informed by the national policy. In this context housing is the competence of the national and provincial spheres. Municipalities as developers are charged with actualization in housing development. As Ndinda et al. (2011) argue, provinces are required to accredit municipalities to support and strengthen their capacity to implement housing programmes. This research discovered that the weakness of rural municipalities in the postapartheid technology of rule has forced them to rely on the upper levels of government to supplement their resources. In essence these municipalities rely on upper levels of government for the financing of capital projects such as housing.

The purification of space does not only affect beneficiaries in the participatory processes of planning phase, it also affects governmental institutions. For example, there is a plurality of key government departments who 
exercise power in housing development during the planning phase of state-initiated self-help housing - but all depends on a housing instrument or scheme. The key government departments for the rural housing subsidy are the DoHS, Department of Land Reform and Rural Development (DLRRD), Department of Cooperative Governance and Traditional Affairs (CoGTA), and Department of Water and Sanitation, amongst others. These governmental institutions are responsible for implementing specific pieces of legislation which define both their specific roles and operational structures. Viewed from the perspective of State-based arrangements, these departments are hierarchical and have top-down forms of setting the rules, exercising power and mobilizing technologies of government involving policing, bio-political knowledge and bureaucratic rule (Swyngedouw, 2005). It is worth noting that these departments are located in different ministries, creating bureaucratic challenges in land administration.

On the one hand, parties involved in the housing projects in the construction process such as implementing agents have come to dominate the administrative networks of housing development, forming a housing development administrative bloc where they gain their hold upon the machinery of government through their inculcation into a professional corps of administrative experts, specialists both in techniques of management and those of numeracy. These implementing agents have to interact with all these departments in the process of housing development, securing and concluding Development Rights with the DLRRD. Rose and Peter (1992) view assembling and maintaining such networks as entailing struggles, alliances and competition between different groups for resources, recognition and power. This means the implementing agents operate in a complex administrative structure when they try to link aspirations of authorities or clients with the lives of individuals both as citizens and subjects.

On the other hand, implementing agents have invented and installed themselves in both the DoHS and CoGTA through local municipalities as a developer, and outside them. The agents articulated the way in which they can provide solutions to the problem of housing delivery. The DoHS as a funder did not want to run out of control. As a result, DoHS set up its Technical Advisory Committee (TAC) for approval of proposed projects and to promote quality management from the planning phase. Managers rather than implementing agents have become more powerful actors in this new network, and power flows from the top - the bureaucratic and political elite - down to the operating of street-level bureaucrats. This was one way of facilitating the creation of domains in which political decisions are dominated by technical calculations. In addition, this mode of action at a distance, increases the possibilities of governing the housing networks, which are located within government and outside government. In a nutshell, TAC is an alibi for the State to maintain some of the power in house delivery. This TAC is made up of technocrats that approve what projects to go through. It means power operates best when it comes in guises. In this instance it is an exercise under the guise of quality control. This again proves Foucault assertion that "power is obitiquous", indeed it is everywhere no assemblage is free of exercise of power. In essence bureaucracy or democracy might appear as a sharing of power but it is not rather it simply serves to strengthen and multiply it in a few hands.

\subsection{State-initiated Self-Help and Practices of Assemblage Housing Development}

In the post-apartheid technology of rule the government has worked by installing what Rose and Peter (1992) might term a "calculative technology" in neoliberal housing governance in order to embed new methods of calculation that will link private decisions and public objectives through the medium of knowledge, and to hold power. The evidence has been drawn from documents of the Ndumo Housing Project (part of Ndumo Regeneration Programme) authored by consultants that DoHS in KwaZulu-Natal assigned funding in order to quantify the housing need through a door-to-door survey. The survey revealed that 2140 in situ housing units for ward 16 were required, rather than the 1000 initially requested by the local municipality of Jozini. This shows that the latter's estimation was informed by insufficient scientific calculation, which may be the result of a lack of State capacity in 
local government (Koelble and Edward, 2010). However, evidence from the Human Settlement Development Plan (HSDP), which serves as the planning technology for housing development of the municipality and council resolution shows that the implementing agents continued to plan for 1000 in situ housing units, which they already locked in. Rose and Peter (1992) argue that 'government articulated a notion of statistics, or science state, in which the operation of government was to be made possible by the accumulation and tabulation of facts about the domain to be governed'. They further note that information from statistics allow a way of devising techniques for ascribing them in such a way as to make the domain in question susceptible to evaluation, calculation and intervention.

According to Rose and Peter (1992) figures transform the domain to which the government is applied. In this context, in enabling events to be aggregated across space and time, figures reveal and construct norms and processes to which evaluations can be attached and upon which interventions can be targeted. They argue that 'the figures themselves are mechanisms that enable relations to be established between different phenomena, rendering "the population", "the economy", "public opinion" ... into thought as calculable entities with a solidity and a density that appears all their ow' (Rose and Peter, 1992). Numbers are manipulated to create the "convenient truth" and act as motivators for certain actions to be taken. This however leads to disastrous effects on the ordinary person, but numbers are power and power is in numbers whether literary or statistically.

The survey noted above provided government with information flows from the local level to the province in order to lay a claim to legitimacy for their plan and strategies, because they are in a real sense in the know about which they seek to govern. As a result, information from the survey helped to inform phase two of housing development in the defined territory, at the same time forcing the local population to be responsible for their own development. In essence, this served as a mechanism for instructing agents in the techniques of accounting.

Municipalities have to involve economic and political elites as well as community as an agency who are crucial to the task of governing in a neoliberal world (Dean, 1999) and all these actors are crucial in the drafting of both the IDP and HSDP. Therefore, municipal council meetings remain a key "discursive space" for the approval of both the IDP and HSDP in the post-apartheid technology of rule. Consequently, the IDP as a new planning technology in an advanced liberal government of housing development requires actors in the non-profit sector, economic sector and government at all spheres, together with community as an agency, to engage in "partnerships" to contribute to the promotion of sustainable human settlements. This is discussed at length below. Overall, the expedient use of other agencies and individual agents as housing delivery vehicles allows municipalities to give the appearance of governing at a distance.

Different forces come together to form an assemblage to assist in the three phases (planning, design and construction) of housing development. This involved an array of agents (conveyancing and legal experts, land surveyors, geotechnical experts, environmental experts, civil engineers, project managers and planners), with different legal and professional structures. Moreover, other agents (villagers, labourers, entrepreneurs, officials, activists, scientists) are involved, with different objectives (profit, pay, livelihoods, control, property, efficiency, sustainability, conservation). Therefore, these latter agents play a crucial role in producing "governable spaces" (Rose, 1999). However, it would be difficult to draw a conclusion that individuals are not merely subjects of power, but play a part in its operations (Rose and Peter, 1992).

The complex interplay of agents, powers and institutions came to play a crucial role in establishing the possibility and legitimacy of government through housing development. These agents are a hegemonic probusiness bloc which has "expert technical authority", uses technical language, and follows procedures to identify "legitimate actors" and produce documents which constitute authoritative knowledge, to give effect to government ambitions. Within the processes of pre-feasibility studies, these agents develop clear rules and establish procedures specifying who is to participate and through which organizational mechanisms. In essence, these agents are 
endowed with capacity to raise funds ${ }^{1}$ and profits and pursue their interests, backed by the virtual monopoly of legitimate use of people's needs, views, and interests as well as opinions and information in a defined territory - all in the name of housing development projects. A closer observation reveals that the performance of this hegemonic pro-business bloc in housing development is monitored by state agencies (such as the DoHS as a funder for housing development and the municipality as a developer) through administrative power, which is in line with 'neoliberal governmentality' (Blakeley, 2010) which protects the state in its power and knowledge that privileges it as the primary locus of authority (Jeffrey et al., 2012).

\subsection{Reassertion of Power and Social Control}

Participatory processes to planning attempt to challenge the apparent power relations in society by recognizing the control that certain individuals and groups. Kothari (2001) points out that the recognition that those who wield power have limited opportunities to express their interests and needs and are generally excluded from key decisionmaking processes, and that their knowledge is considered insignificant. We notice that the act of inclusion where individuals or potential beneficiaries are drawn as participant symbolize an exercise of power and control over an individual. For example, poor people in rural areas have always been provided with a rural housing subsidy, since it was identified and promoted as a suitable mechanism for rural development; this technological device is guaranteed to those with informal rights to land. The question of informal rights to land and the housing subsidy scheme were also guaranteeing the indirect technology of rule, where individuals relate with the State as members of a certain community (village, tribe), and interact with the State for the rural housing subsidy through traditional councils. A significant difference in formal governance between the rural and urban is the institution of the hereditary chieftaincy. In South Africa's bifurcated regimes of governance and citizenship, urban residents are the "citizens" of civic authority while the rural residents in the communal area of the former homelands are the partial "subjects" of hereditary traditional authority (Mamdani, 1996). Chiefs dispense (often uneven) rural governance and exercise much of their authority in relation to local land administration and the adjudication of disputes. Many of the beneficiaries of state-initiated self-help housing were identified and derive their right to access to housing from communal recognition.

\subsection{Managing Complexity in State-Initiated Self-Help Housing Development}

The local government and the traditional council, through the housing implementing agent, captured a participatory discourse during state-initiated self-help housing by establishing the Project Development Committee (PDC) to be an authoritative voice of beneficiaries. The PDC comprised 15 members who were elected in a community meeting, but not through a 'secret ballot' box but through a show of hands. Access to the PDC was restricted, and by carefully selecting community activists and the affluent to be on it, the implementing agent, local municipality and traditional council were able to influence who is qualified to speak in the name of housing development in the defined territory (at ward level) during the planning phase. This conclusion has been drawn from the constitution ${ }^{2}$ of the housing committee, authored by the municipality and the implementing agent.

The Community-Based-Partner (CBP) Constitution states that 'the main aim of the committee is to represent the needs, views and interests of the Ndumo Beneficiaries residing in the Mathenjwa Traditional Authority within the Jozini Municipality regarding all housing matters'. Given this state of affairs, establishing such an authoritative voice on housing development under the defined territory was considered essential as a basis for engagement with the community to gain acceptance of the product to be delivered. ${ }^{3}$ The PDC may thus be understood as the

\footnotetext{
${ }^{1}$ Implementing agents are also tasked by the municipalities with the submission of applications for funding to the DoHS.

${ }^{2}$ This document is known as Jozini Ward 16 (Ndumo) Turn Key Housing Project, Community-Based-Partner Constitution (CBP).

${ }^{3}$ See Report to the Project Steering Committee (PSC), 13 May 2014).
} 
administrative space created by the implementing agent, through powers assigned to him by DoHS and local municipality, where they extended their biopolitical mission of using and optimizing the forces and capabilities of 'quality of life' to the entire 'municipal territory'.

The PDC was not the only structure established during the planning phase so as to render housing development governable at a community level. The PSC was also established in March 2014, and comprised 12 members ${ }^{4}{ }^{2}$ most from the community and part of the PDC. The PSC can be interpreted as a clear example of 'advanced liberal government' (Dean, 1999). Oels (2005) argues that advanced liberal government draws on markets, technologies of agency and technologies of citizenship to create "responsible", "calculating” member states. The targeted deliverables and timetables of the implementing agent and turnaround payment period by State agencies can be understood as an example of "new contractualism” fostered by technologies of agency, thereby binding as "responsible" each institution through a representative to a shared objective of housing delivery (Oels, 2005). The extensive deliberations at both monthly and quarterly meetings can be considered as an effort to establish deliberative spaces (technologies of citizenship) in which each representative shapes their identity as responsible and calculating to the PSC. The PSC operates in 'invited spaces'. The PSC can be seen as a dominant structure which creates sanctioned spaces of participation which is in line with neoliberal governance in low-density democracies (Miraftab, 2009).

Representatives are forged as "calculative" agents, but have limited powers of making responsible choices, because they prevent "popcorn protest" (Mottiar, 2013) as housing has for a long time been at the centre of South African politics of protest (Ndinda et al., 2011). On the one hand, the PDC as representatives of indigenous people found representation on the PSC for purposes of monitoring, valuation and benefits-sharing as well as technical capacity building (Mauro and Preston, 2000). On the other hand, at worst, PDC members have been drawn into practicing technologies of advanced liberal government (Bracking, 2014) which disempowers and displaces them from identifying real beneficiaries among the "deserving poor" rural individuals. The "deserving poor" are left to be identified by the traditional elite through implementing agents in exchange for land, but remain obliged through regular progress reports to provide a 'defined territory of rule and a project and apparatus for administering the lives and activities of those within the territory' (Rose and Peter, 1992).

Housing development through the implementation of the planning phase brought changes in governance with establishment of both the PDC and the PSC. Establishment of these two structures did not serve to strengthen community involvement or the needs of indigenous populations, but facilitated close relationships with business entrepreneurs involved in housing development to forge relationships around the Ndumo Regeneration Programme, and "professionalization" of citizen participation which has become a technology of government (Kapoor, 2005). Blakeley (2010) argues that governing at a distance through relying on the self-governance capacities of people, organizations and communities means that expertise comes to play a crucial role as experts mediate between the actions of political authorities and the objects - jurisdictions, persons, groups, and so forth that fall under their responsibility'.

PDC and PSC representatives were notables located in both rural indigenous community and state agencies. Blakeley (2010) concurs that 'participation of notables' occurs whereby experts or professionals take part, rather than the ordinary citizen. In addition, as Blakeley (2010) concludes: 'as power is exercised through the discourse and organizational forms of these formal instances of participation, citizens often adapt their language and behavior as they become more involved'. Overall, representation in the PSC was connected to different circuits of powers, but PDC representatives to the PSC were vulnerable, such that they only had to consent to plans that had already been

${ }^{4}$ There are two representatives from the local municipality as a developer, two representatives from KwaZulu-Natal DoHS as a funder, two representatives from the implementing agent, two representatives from a community-based partner (which is a traditional council) as having given the land or housing development, and four representatives from the community as they represent the beneficiaries. 
established (rather than shaping plans from the start) as well as consent to the space opened for traditional council to identify potential beneficiaries, which also contributed to the "resurgence" of the traditional leadership institution to re-enter local politics.

The housing development planning process allowed for developers (municipalities) to appoint implementing agents through "turnkey" contract strategies which allowed implementing agents to enjoy hybrid-private status. This conclusion has been drawn from documents authored by municipalities and consultants (implementing agents), whose appointment process was dubious and whose qualifications remain unknown, but with remarkable influence for appointment from political elites and little credible supplementary information from previous clients or indeed inputs from housing experts and the indigenous community.

The pressure for municipalities to deliver as housing developers, combined with their weak institutional and financial capacity, prevented them from following procurement processes and allowed implementing agents to appoint business enterprises of their choice with no proof of having successfully implementing development projects. This is grounded in the opportunity structure which promotes business enterprises known to the implementing agent(s) and encourages business cronyism. As Bracking (2007) argues, a closed culture of business enterprise provides ample opportunity for corrupt business practices, while providing incentives to political elites to behave similarly or act on behalf of or within subcontracted business enterprises. A common feature is that the postapartheid technology of rule provides implementing agents with ample space to appoint a full team of qualified and experienced experts in consultation with the municipality, justified by "successful track record" on paper without this being verified. However, granting of such power to implementing agents may result in escalation of poorquality houses, as professionals may choose not to discipline or hold each other accountable for fear of disrupting future business opportunities and obstructing payment opportunities from the funder of housing development.

\subsection{Land Administration and Traditional Councils}

Traditional authorities managed to secure their constitutional recognition and protection in both the 1993 Interim Constitution as well as the final Constitution of 1996. This recognition and protection for an "official rural patriarchal authority" in South Africa's "liberal" Constitution confirmed that they will play a role in all development activities, including state-initiated self-help housing development. The government was concerned about the project of state formation and nation building, and needed to construct structures that would in turn provide for government to govern and control.

However, municipalities in KwaZulu-Natal now find it very difficult to control development in their municipal area of jurisdiction, because of the land question, which falls under the ownership of the Ingonyama Trust. For municipalities to fulfil their developmental mandates they are required to sign a Development Rights Agreement, following the grant approval by any department that requires delivering a particular service through the municipalities. For example, the rural housing subsidy cannot be implemented without the consent of traditional councils, which makes them serve as supreme structures when it comes to land allocation for state-initiated self-help housing development. Worth noting is that in KwaZulu-Natal the dual system for land allocation and administrative powers and functions exists in communal areas, such that it was made very explicit that there should be no interference with land administration for development - rather, the Zulu King, through the Ingonyama Trust Board, was given powers to distribute land for capital projects; and that became a form of control that has been more difficult to challenge.

\section{CONCLUSION}

This paper has reviewed a literature on self-help housing. It was shown that self-help housing practice has existed among cultures of developing countries since time immemorial before conventional town planning and 
housing knowledge. The paper that there are different types of self-help housing, and the paper focused on the participatory processes of the planning phase of state-initiated self-help in Jozini Municipality.

Moreover, the paper has shown that in the new governance culture of housing development, State officials work with traditional councils as partners in housing development. The alliance between traditional councils and State officials operates in three ways: 1) traditional councils have status on the PSC, 2) traditional councils provide consent to land for housing development, and 3) traditional councils are given first priority in the identification of housing beneficiaries.

Funding: This study received no specific financial support.

Competing Interests: The authors declare that they have no competing interests.

Contributors/Acknowledgement: Both authors contributed equally to the conception and design of the study.

\section{REFERENCES}

Blakeley, G., 2010. Governing ourselves: Citizen participation and governance in Barcelona and Manchester. International Journal of Urban and Regional Research, 34(1): 130-145. View at Google Scholar | View at Publisher

Bracking, S., 2007. Accountability in development finance projects: Between the market and a soft place. In corruption and development: Anti-corruption campaigns, edited by Sarah Bracking. Britain: Palgrave Macmillan. pp: 236-257.

Bracking, S., 2014. Anti-politics of climate finance: The creation and performativity of the green climate fund. Antipode, 47(2): 281-302. View at Google Scholar | View at Publisher

Burgess, R., 1977. Self-help housing: A new imperialist strategy? A critique of the turner's school. Antipode, 9(2): 50-59. View at Google Scholar | View at Publisher

Cleaver, F., 1999. Paradoxes of participation: Questioning participatory approaches to development. Journal of Interntional Development, 11(1): 597-612. View at Google Scholar | View at Publisher

Dean, M., 1999. Governmentality: Power and rule in modern society. London: Sage Publications.

Dewar, D., P. Andrew and V. Watson, 1981. Low-income housing procurement in South Africa: Additional options. Cape Town: University of Cape Town.

Duncan, S.S. and A. Rowe, 1993. Self-provided housing: The first world's hidden housing arm. Urban Studies, 30(8): 1331-1354.

View at Google Scholar | View at Publisher

Ferguson, J., 2010. The uses of neoliberalism. Antipode, 41(1): 166-184. View at Google Scholar | View at Publisher

Foucault, M., 1980. The history of sexuality. New York: Vintage.

Harris, R., 1998. The silence of the experts: “Aided self-help housing”, 1939-1954. Habitat International, 22(2): 165-189. View at Google Scholar | View at Publisher

Harris, R. and C. Giles, 2003. A mixed message: The agents and forms of international housing policy, 1945-1973. Habitat International, 27(2): 167-191. View at Google Scholar | View at Publisher

Jeffrey, A., C. McFarlane and A. Vasudevan, 2012. Rethinking enclosure: Space, subjectivity and the commons. Antipode, 44(4): 1247-1267. View at Google Scholar | View at Publisher

Kapoor, I., 2005. Participatory development, complicity and desire. Third World Quarterly, 19(8): 1203-1220. View at Google Scholar । View at Publisher

Koelble, T. and L. Edward, 2010. Institutional obstacles to service delivery in South Africa, social dynamics. Journal of African Studies, 36(3): 565-589. View at Google Scholar | View at Publisher

Kothari, U., 2001. Power, knowledge and social control in participatory development. In B. Cooke, \& U. Kothari, Participation: The New Tyranny. London: Zed Books. pp: 139-152.

Mamdani, M., 1996. Citizen and subject: Contemporary Africa and legacy of late colonialism. Princeton NJ: Princeton Univ ersity Press. 
Mathey, K., 1997. Self-help approaches to the provision of housing: the long debate and a few lessons, in: J. Gugler (Ed.) Cities in the Developing World. Issues, Theory and Policy. New York: Oxford University Press. pp: 280-290.

Mauro, F. and H. Preston, 2000. Traditional knowledge of indigenous and local communities: International debate and policy initiatives. Ecological Applications, 10(5): 1263-1269. View at Google Scholar | View at Publisher

Miraftab, F., 2009. Insurgent planning: Situating radical planning in the global South. Planning Theory, 8(1): 32-50. View at Google Scholar | View at Publisher

Mottiar, S., 2013. From 'popcorn' to 'occupy': Protest in Durban, South Africa. Development and Change, 44(3): 603-619. View at Google Scholar | View at Publisher

Myeni, S.L. and B.Y.C. Mvuyana, 2015. Rethinking administrative accountability and the rule of law in housing development in South Africa. Journal of Public Administration, 50(4): 788-800. View at Google Scholar

Ndinda, C., U. Ufo and W. Lolita, 2011. From informal settlements to brick structures: Housing trends in post-apartheid South Africa. Journal of Public Administration, 46(1.1): 761-784. View at Google Scholar

Ntema, L.J., 2011. Self-help housing in South Africa: Paradigms, policy and practice. Unpublished PhD Thesis, University of the Free State, South Africa.

Oels, A., 2005. Rendering climate change governable: From biopower to advanced liberal government? Journal of Environmental Policy \& Planning, 7(3): 185-207. View at Google Scholar | View at Publisher

Pugh, C., 2001. The theory and practice of housing sector development for developing countries, 1950-99. Housing Studies, 16(4): 399-423. View at Google Scholar | View at Publisher

Rose, N., 1999. Inventing ourselves: Psychology, power, and personhood. Cambridge: Cambridge University Press.

Rose, N., 2000. Government and control. British Journal of Criminology, 4O(2): 32 1-339. View at Google Scholar

Rose, N. and M. Peter, 1992. Political power beyond the state: Problematics of government. British Journal of Sociology, 43(2): 173-205. View at Publisher

Seekings, J., 2000. Introduction: Urban studies in South Africa after apartheid. International Journal of Urban and Regional Research, 24(4): 832-840. View at Google Scholar | View at Publisher

Sengupta, U., 2010. Government intervention in public private partnership in housing in Kolkata. Habitat International, 30(3): $448-461$.

Sibley, D., 1995. Goegraphies of exclusion. London: Rutledge.

Soliman, A.M., 2004. A possible wayout: Formalising housing informality in Egyptian cities. United States: University Press of America.

Stein, A., 1991. A critical review of the main approaches to self-help housing programmes. London: University College London.

Swyngedouw, E., 2005. Governance innovation and the citizen: The janus face of governance-beyond-the-state. Urban Studies, 42(11): 1991-2006. View at Google Scholar | View at Publisher

Tait, J., 1997. From self-help housing to sustainable settlement: Capitalist development and urban planning in Lusaka, Zambia. England: Avebury Publishers.

Turner, J.F.C., 1972. The re-education of a professional and housing as a verb, In: J. Turner and R. Fichter (Eds.) Freedom to Build. New York: Macmillan.

Ward, P.M., 1982. Self-help housing: A critique. London: Mansell.

Zhang, L., S.X.B. Zhao and J.P. Tian, 2003. Self-help in housing and chengzhongcun in China's urbanization. International Journal of Urban and Regional Research, 27(4): 912-937. View at Google Scholar | View at Publisher 